\title{
Med livet som innsats
}

\author{
I en episode av TV-serien Med livet som innsats skulle en vannfilm beskytte en person som gled gjennom \\ parafinflammer. Den påførte vannfilmen var i denne settingen langt fra tilstrekkelig for å hindre alvorlige \\ brannskader. Heldigvis slapp personen unna med symptomer tilsvarende lett solbrenthet på deler av kroppen. \\ Hvorfor?
}

Det synes å være en del av tidsånden at enkelte TV-serier stadig strekker grensene inn $\mathrm{i}$ gråsonen for hva som kan regnes som forsvarlig. NRKs serie Med livet som innsats er en av disse. Serien har mange likhetstrekk med programmet MythBusters.

Programleder Andreas Wahl i serien er velutdannet med en MSc-grad i fysikkdidaktikk, godt trent og selvdisiplinert. Han konsulterer eksperter før forsøk skal gjennomføres og diskuterer mulige løsninger med sine medhjelpere. De lager deretter utstyret han trenger til sine forsøk. Eksempler kan være sugekopper for å klatre på fasader, Faraday-bur for beskyttelse mot store elektriske utladninger etc.

I motsetning til søkelys på mange barrierer mot uhell i MythBusters (1) skal kun fysikken og programlederens egenskaper hindre uhell i den norske serien. Dersom faremomentene ikke fullt ut er forstått, kan slike stunt gå fryktelig galt.

\section{Grillet levende}

I episoden Grillet levende skulle programlederen på en tralle, kun iført shorts og lue av ull, gli gjennom 2-3 m flammer fra en parafinbrann. Konseptet var inspirert av at man kan bevege en finger gjennom en talglysflamme. Her skulle imidlertid flammene være store nok til å dekke hele personen. Før turen gjennom flammene ble han fuktet med vann for å demonstrere at en tynn vannfilm ville beskytte mot flammene. Fagpersonell innen brannsikkerhet og medisin ble konsultert. Samtlige var meget skeptiske og la vekt på risikomomenter forbundet med inhalering og hudskader (2).

Programlederen (1,93 m høy, $100 \mathrm{~kg})$ akselererte på en $12 \mathrm{~m}$ lang skrå stålbane gjennom flammene og ned $i$ et vannbasseng. Banens helning var justert for å gi en hastighet på $14 \mathrm{~km} / \mathrm{t}$ (3,9 m/s). Pølen med parafin var 2,24 $\mathrm{m}$ lang og $0,86 \mathrm{~m}$ bred. Eksponeringstiden i flammesonen var om lag $0,74 \mathrm{~s}$. Etter $4-5 \mathrm{~s}$ kjøling i bassenget klatret han ut og rapporterte videre (2).

Programlederen har senere opplyst at han følte en kort, stikkende smerte før eller akkurat da han havnet i bassenget: «Som om jeg ved et uhell hadde lent meg inntil en varm ovn, eller noe lignende, og instinktivt trakk unna de lemmene som hadde kommet i kontakt med den varme flaten.» Etterpå følte han seg overraskende varm: «Jeg hadde en følelse av varme som bredde seg gjennom kroppen». Han tenkte at dette var tilsvarende varmefølelse som etter en svøm- metur i kaldt vann, isbad etc., men kunne ikke utelukke oppmagasinert varme i hud og underhud. I samtaler forklarte programlederen senere at han var «høy på adrenalin», hvilket kan ha påvirket sansene. Sammenlignet med andre hevder han at han har høy terskelverdi for smerte i sauna, ved isbading etc. (Andreas Wahl, personlig meddelelse).

På deler av kroppen hadde han sotmerker (fig 1). Deler av huden vurderes derfor til å ha tørket fullstendig på turen gjennom flammene. Ti minutter etter eksponeringen oppfattet han at han var blitt lettere brent, tilsvarende lett solbrent på mesteparten av ryggen $(\sim 40 \mathrm{~cm} \times 60 \mathrm{~cm})$, under armene, under lårene og under leggene (hver ca. $\sim 5 \mathrm{~cm} \times 30 \mathrm{~cm}$ ). Følelsen av å være solbrent, med delvis rød hudfarge, var tydelig noen timer senere: «Jeg kjente det godt da jeg gikk for å legge meg.» Følelsen av å være «lett solbrent» forsvant imidlertid helt etter 24-36 timer. Hårveksten kom tilbake som normalt, og det ble ingen permanente skader.

Motivasjonen for denne studien er å vise at et tynt vannlag ikke beskytter særlig i store flammer. Eventuelle andre mekanismer som beskyttet mot varmepåvirkningen i dette konkrete tilfellet dokumenteres. Læringsutbytte kan være at andre advares mot tilsvarende stunt uten fullt ut å forstå involvert risiko, behov for sikkerhetsbarrierer og betryggende marginer.
Ifølge Gaydon og Wolfhard forventes en flammetemperatur opp mot $1000{ }^{\circ} \mathrm{C}$ i parafinbranner (3). Programlederen var dypt konsentrert, unngikk inhalering og holdt øynene lukket uten endret oppførsel da smertereseptorene på ca. $0,1 \mathrm{~mm}$ dybde ble aktivert ved en temperatur på $44,8^{\circ} \mathrm{C}(4,5)$. Faremomenter ved inhalering og øyeskader er derfor ikke videre analysert.

\section{Brannskader}

Brannskader på eksponert hud utvikles ved temperaturer over $44^{\circ} \mathrm{C}$ i basallaget til epidermis som følge av nedbrytning av proteiner (6-8). Flammetemperaturer nær $1000^{\circ} \mathrm{C}$ representerer derfor en betydelig trussel mot huden, selv ved meget kort tids eksponering.

Etter annen verdenskrig ble det publisert en rekke studier av termiske brannskader i The American Journal of Pathology. Disse artiklene inkluderte varmetransport til og gjennom svineskinn med temperaturmålinger (9).

Viktigheten av tid og overflatetemperatur for brannskader ble studert, og patologi og patogenese for dypere brannskader ble også studert (10). En modell for termisk varmeskade i hud ble utviklet av Jackson (11). Denne modellen har dannet basis for forståelse og anatomisk dybdeinndeling av brannskader som overflatiske epidermale skader, dermale delhudsskader og trans-

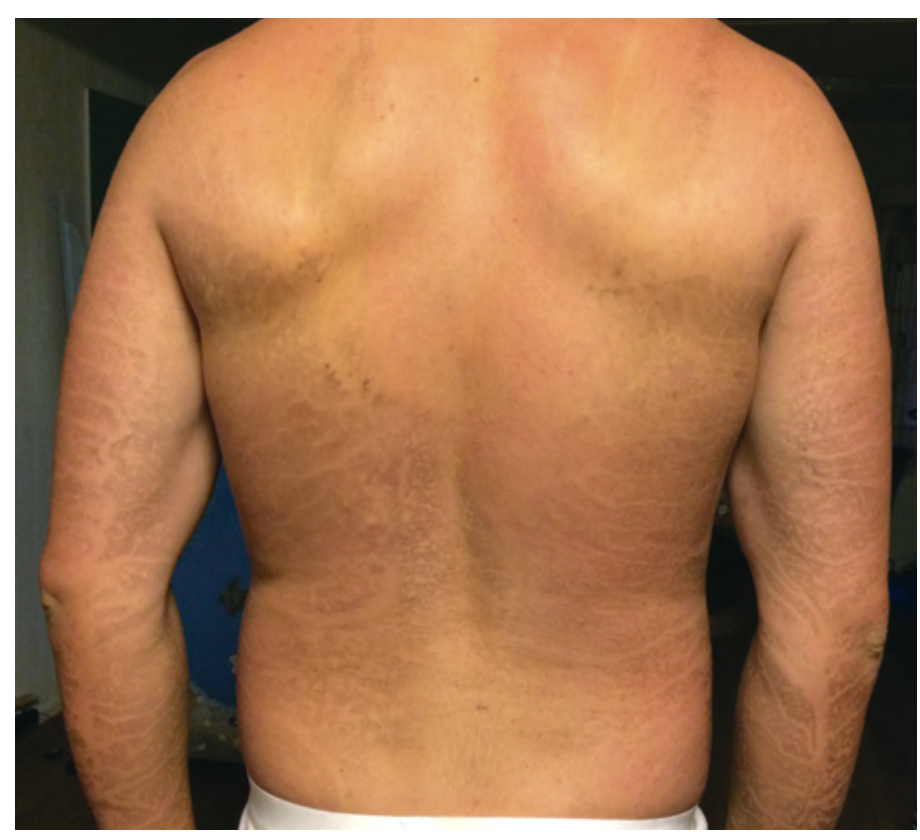

Figur 1 Sotmerker på armer og rygg. Gjengitt med tillatelse. Foto: Andreas Wahl 


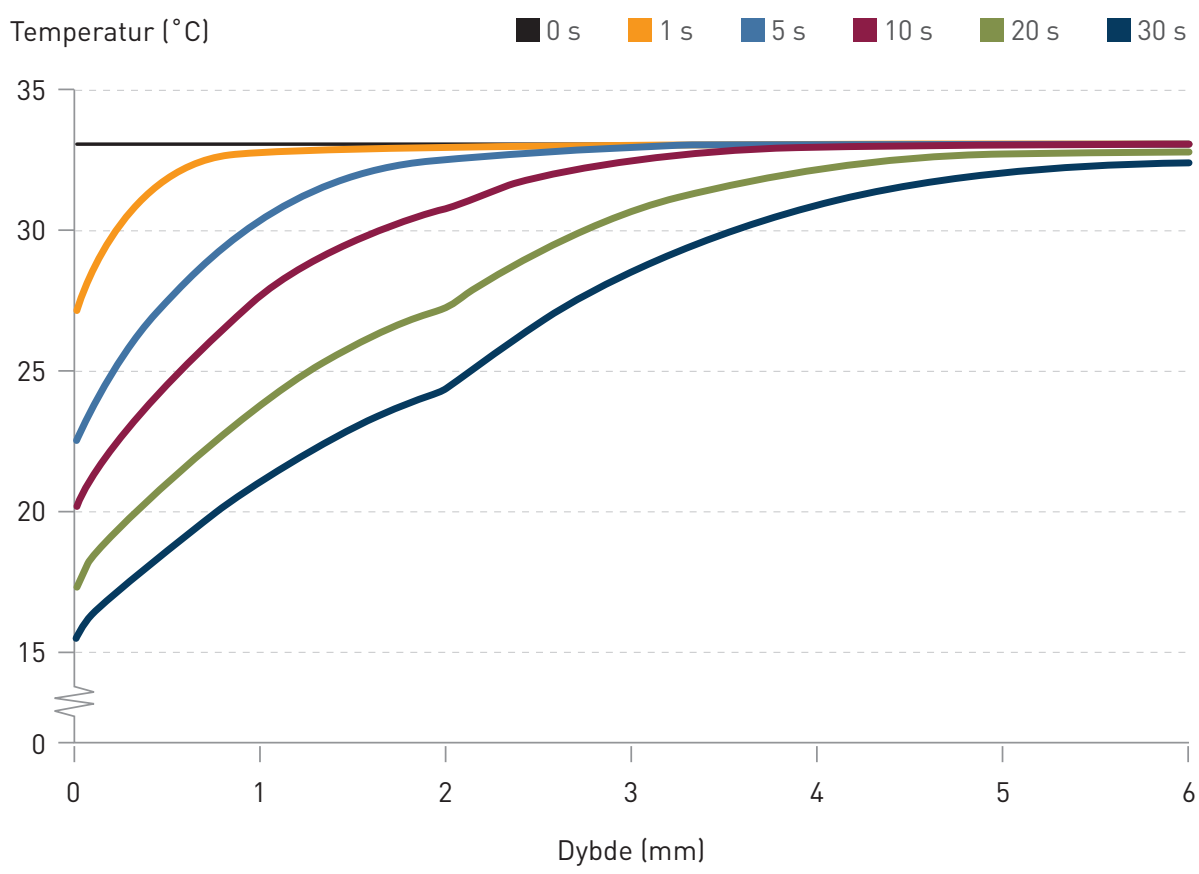

Figur 2 Utvalgte temperaturprofiler i huden ved fukteperioder av ulik varighet og med $6{ }^{\circ} \mathrm{C}$ vanntemperatur (25) og subdermale fullhudsskader, henholdsvis skade grad 1, 2 og 3. I tiden umiddelbart etter forbrenningen øker skadedybden med tid (11). Initial vurdering av dybde av brannskader er vanskelig, men avgjørende for behandlingen (11).

Brannskadet areal (prosentandel av kroppsoverflaten) er av meget stor betydning for overlevelsesevne (12). Monstrey og medarbeidere gir en oversikt over metoder for å beregne dybde av brannskader og potensial for tilheling (13). For beslutningsstøtte i forhold til behandlingsmetoder anbefales laserdoppler (LDI). Initial vurdering baseres gjerne på telemedisin der man overfører bilder fra mobiltelefon til eksperter og mottar råd og veiledning (13). Det er også mye søkelys på å utvikle vernetøy etc. for beskyttelse mot varmeeksponering (14).

\section{Forskningsresultater}

I den senere tid er det også blitt gjennomført forskning på førstehjelpsfaktorer som påvirker brannskader (15) og behandling av skadene (16). Wright og medarbeidere oppsummerer nyere forskning som viser at vannkjøling fungerer bra og at effekten går langt utover ren termisk kjøling (17). Umid-

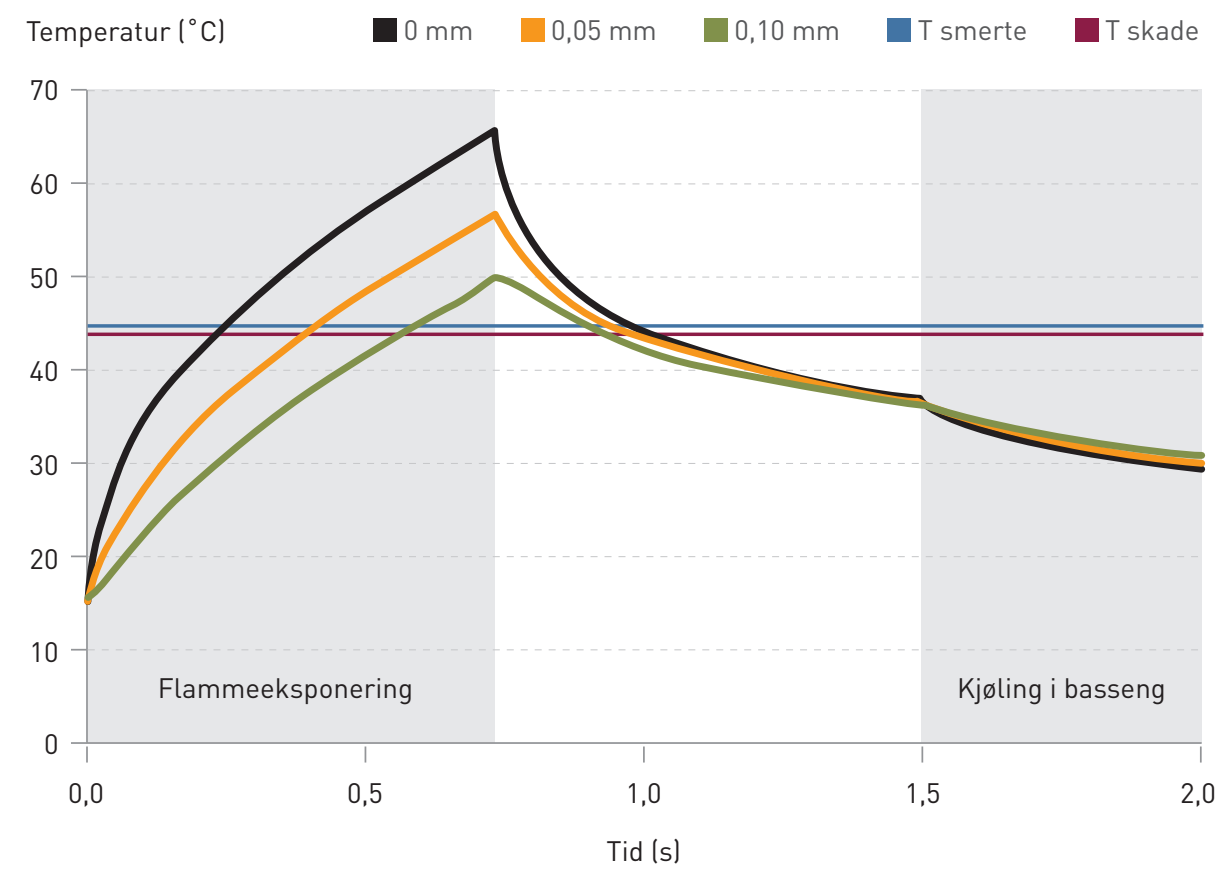

Figur 3 Temperatur under og etter flammeeksponering ved oppgitt dybde i huden (25) delbar vannkjøling i 20 minutter etter eksponering ga for en større pasientgruppe i Australia og New Zealand $13 \%$ reduksjon $\mathrm{i}$ behovet for hudtransplantasjoner. I tillegg ble intensivbehandlingen nær halvert, og lengden på sykehusoppholdet ble i gjennomsnitt redusert med 2,27 dager (18).

Hudsimulatorer er bygd for å studere varmetransport og sammenligning med måling av temperatur i etterlignet hud med konkalorimeter (19). Jiang og medarbeidere har vist at tykkelsen av epidermis og dermis, som de modellerte med forskjellige egenskaper, påvirker resultatene betydelig (20). De viste også at mindre variasjon i initialtemperatur, små temperaturgradienter og blodgjennomstrømning hadde liten effekt.

Fu og medarbeidere var enig $i$ at blodgjennomstrømningen i dermis hadde liten effekt på brannskader, og de konkluderte med at forskjellig varmeledningsevne og varmekapasitet $i$ epidermis og dermis hadde liten betydning (15).

Van de Sompel og medarbeidere viste at Arrhenius skadeintegral nær hudoverflaten gjennom rask nedkjøling var for liten til å være fysiologisk relevant (21). Reduksjonen i overflatetemperaturen var raskere, men den terapeutiske fordelen med kjølingen kunne ikke alene forklares termisk. Disse arbeidene viser at temaet er komplekst, resultatene avhengig av hver enkelt situasjon, og langt fra alle faktorer av betydning er kartlagt (17).

Varmefluksen man utsettes for ved flammeeksponering, er foruten flammens temperatur avhengig av en rekke faktorer, så som brenselets kjemi, lufttilgang, optisk tykkelse av flammen, flammens relative hastighet til det eksponerte objektet etc. En vannfilms kjøleevne i en slik setting er avhengig av vannfilmens tykkelse, temperatur, diffusjonskoeffisient for vanndamp i luft, diffusjonssjiktets tykkelse, som igjen er avhengig av relative hastigheter etc.

Varmetransport inn i huden er en funksjon av de forskjellige hudlagenes tykkelse og termiske egenskaper, i tillegg til at skadepotensial er avhengig av så vel tid som temperatur (eksponentielt). Flere av disse parameterne er ikke-lineære.

Flammeeksponering av våt hud er derfor en komplisert problemstilling. Ved å lage en numerisk modell for varmetransport $i$ hud og benytte kjent fysikk angående fordamping av vann (22) og varmetransport i flammer (23) er det likevel mulig å gjøre overslagsberegninger av temperaturprofiler og Arrhenius skadepotensial (24). I en pasient-kontroll-studie som dette vil nøyaktigheten i stor grad være avhengig av bakgrunnsinformasjonen man klarer å skaffe.

Ved å kombinere varmestråling og konvektiv varmetransport fra den aktuelle flammen, energiopptak ved oppvarming og fordamping av en vannfilm og varmetransport inn i hudens lag, kan man analysere seg frem til temperaturutviklingen i en slik 
situasjon (25). Med $6{ }^{\circ} \mathrm{C}$ vanntemperatur blir beregnede temperaturprofiler i huden under $30 \mathrm{~s}$ fuktperiode som vist i figur 2. Temperatur på hudens overflate og i $0,05 \mathrm{og}$ $0,1 \mathrm{~mm}$ dybde under flammeeksponeringen er vist i figur 3.

Basert på beregninger med $0,1 \mathrm{~mm}$ tykk vannfilm fikk ikke programlederen førstegradsforbrenning (skadeintegral $\Omega=0,03$ ). Beregningene viser imidlertid at et slikt vannlag ikke ville rekke å tørke helt. I og med at vannlaget tørket fullstendig noen steder, må det der ha vært tynnere enn $0,1 \mathrm{~mm}$. Beregninger med 0,05 mm tykt vannlag og $20 \mathrm{~s}$ fukting (vannkjøling) antyder skadeomfang tilsvarende annengradsforbrenning på store deler av kroppen $(\Omega=1,55)$. Den rødheten som programlederen beskrev, og som han «kjente godt» noen timer senere, stemmer overens med det man i litteraturen beskriver som epidermal (førstegrads) brannskade (26).

Beregningene er på ingen måte eksakte. De viser likevel at nedkjølingen av huden var en viktigere skadebegrensende mekanisme enn selve vannfilmen. Ettersom skadeintegralet øker svært mye ved kombinasjonen høyere temperatur i basallaget og lengre tidsperiode over $44{ }^{\circ} \mathrm{C}$, ville kortere fukteperiode (nedkjøling) kunne gitt langt mer alvorlige skader. Fukteperioden (nedkjølingen) før flammeeksponeringen var heldigvis tilstrekkelig lang. Dette ga derfor margin mot alvorlige hudskader tilsvarende nedkjøling av hud før laserdermatologi (27).

Jeg takker programleder Andreas Wahl for god kommunikasjon. Han bidro med fotografier av sine sotmerker og har godkjent teksten.

Torgrim Log

torgrim.log@hsh.no
Torgrim Log (f. 1960) er sivilingeniør i uorganisk kjemi og dr.ing. i vametransport fra Norges teknisk-naturvitenskapelige universitet. Han arbeider som rådgiver $i$ teknisk sikkerhet ved Statoil Kårstø og er professor i sikkerhetsfag ved Høgskolen Stord/Haugesund

Forfatter har fylt ut ICMJE-skjemaet og oppgir ingen interessekonflikter.

\section{Litteratur}

1. Zavrel EA. How the Discovery Channel Television show MythBusters accurately depicts science and engineering culture. J Sci Educ Technol 2011; 20: $201-7$

2. NRK. Med livet som innsats - grillet levende. https: //tv.nrk.no/serie/med-livet-som-innsats/ KMTE51001214/sesong-1/episode-2 (26.10.2016).

3. Gaydon AG, Wolfhard HG. Flames: their structure, radiation and temperature. 4. utgave. London: Chapman and Hall, 1979.

4. Buettner K. Effects of extreme heat and cold on human skin. II. Surface temperature, pain and heat conductivity in experiments with radiant heat. J Appl Physiol 1951; 3: 703-13.

5. Lawrence JP, Bull JC. Thermal conditions which cause skin burns. Eng Med 1976; 5: 61-3

6. Stoll AM, Greene LC. Relationship between pain and tissue damage due to thermal radiation. J Appl Physiol 1959; 14: 373-82.

7. Marx J. Thermal burns. Rosen's emergency medicine: concepts and clinical practice. 7. utgave. Philadelphia, PA: Mosby/Elsevier, 2010.

8. Phelps H. Sidhu H. A mathematical model for heat transfer in fire fighting suits containing phase change materials. Fire Saf J 2015; 74: 43-7

9. Henriques FC, Moritz AR. Studies of thermal injury, I: the conduction of heat to and through skin and the temperatures attained therein: a theoreti$\mathrm{cal}$ and an experimental investigation. Am J Pathol 1947; 23: 530-49

10. Moritz AR, Henriques FC. Studies of thermal injury, II: the relative importance of time and surface temperature in the causation of cutaneous burns. Am J Pathol 1947; 23: 695-720.

11. Jackson DM. The diagnosis of the depth of burning. Br J Surg 1953; 40: 588-96.

12. Guttormsen AB, Onarheim H, Thorsen J et al. Behandling av alvorlige brannskader. Tidsskr Nor Legeforen 2010; 130: 1236-41.

13. Monstrey S, Hoeksema H, Verbelen J et al. Assess ment of burn depth and burn wound healing potential. Burns 2008: 34: 761-9.

14. Zhai LN, Li J. Prediction methods of skin burn for performance evaluation of thermal protective clothing. Burns 2015; 41: 1385-96.

15. Fu M, Weng WG, Yuan HY. Numerical simulation of the effects of blood perfusion, water diffusion, and vaporization on the skin temperature and burn injuries. Numerical Heat Transfer, Part A: Applications 2014; 65: 1187-203

16. Tobalem M, Harder Y, Tschanz E et al. First-aid with warm water delays burn progression and increases skin survival. J Plast Reconstr Aesthet Surg 2013; 66: 260-6.

17. Wright EH, Harris AL, Furniss D. Cooling of burns: Mechanisms and models. Burns 2015; 41: 882-9

18. Wood FM, Phillips M, Jovic T et al. Water first aid is beneficial in humans post-burn: evidence from a Bi-National cohort study. PLoS One 2016; 11 : e0147259.

19. Monds JR, McDonald AG. Determination of skin temperature distribution and heat flux during simulated fires using Green's functions over finitelength scales. Appl Therm Eng 2013; 50: 593-603

20. Jiang SC, Ma N, Li HJ et al. Effects of thermal properties and geometrical dimensions on skin burn injuries. Burns 2002; 28: 713-7.

21. Van de Sompel D, Kong TY, Ventikos Y. Modelling of experimentally created partial-thickness human skin burns and subsequent therapeutic cooling: a new measure for cooling effectiveness. Med Eng Phys 2009; 31: 624-31.

22. Log T. Water droplets evaporating on horizontal semi-infinite solids at room temperature. Appl Therm Eng 2016; 93: 214-22.

23. Log T. Cold climate fire risk; a case study of the Lærdalsøyri fire, January 2014. Fire Technol 2016; 52: $1825-43$

24. Wieczorek CJ, Dembsey NA. Effects of thermal radiation on people: predicting 1 st and 2 nd degree skin burns. SFPE Handbook of Fire Protection Engineering. 5. utgave. Redaktør Morgan J. Hurley. Springer, 2015: 2705-35.

25. Log T. Matematisk modellering av nedkjølt fuktig hud eksponert mot hydrokarbonflammer. Intern FoU-artikkel 2016, Høgskolen Stord/Haugesund, $15 \mathrm{~s}$.

26. Lewis GM, Heimbach DM, Gibran NS. Evaluation of the burn wound: Management decisions. Total Burn Care, 4. utgave. Redaktør Herndon DN. New York, NY: Elsevier, 2012

27. Li D, Chen B, Wu WJ et al. Multi-scale modeling of tissue freezing during cryogen spray cooling with R134a, R407c and R404a. Appl Therm Eng 2014; 73 : $1489-500$

Mottatt 17.3. 2016, første revisjon innsendt 3.4. 2016, godkjent 26.10. 2016. Redaktør: Tor Rosness.

Publisert først på nett. 